\title{
Development of Parental Competence Through Psychological and Pedagogical Support for Families in the Upbringing of Hearing-Impaired Children
}

\author{
Lyudmila N. Molchanova ${ }^{\mathrm{a}^{*}}$, Anna V. Chekanova ${ }^{\mathrm{b}}$ \\ ${ }^{a}$ Kursk State Medical University, Kursk, Russia \\ ${ }^{\mathrm{b}}$ Gymnasium No. 1, Severomorsk, Russia \\ *Corresponding author. E-mail: molchanowa.liuda@yandex.ru
}

Background. The need for psychological and pedagogical support for families in the upbringing of hearing-impaired children makes it imperative to develop innovative methods and an effective model of interaction between the family and a special needs educational institution, to improve parental competence.

Objective. To study the psychological content of parental competence (its cognitive, value-motivational; emotional and behavioral components) and to evaluate parental competence through psychological and pedagogical support for families in the upbringing of hearing-impaired children.

Design. Eighty-seven families with hearing-impaired children from a special needs educational institution in Kursk, Russian Federation, participated in the experimental study. The researchers took measurements at two time points, baseline and followup. At baseline, we made a diagnostic assessment of the psychological content of parental competence. At followup, we evaluated the development of parental competence resulting from the psychological and pedagogical support for these families.

Results. The cognitive component was characterized by predominant unanimity between the parents in the upbringing of hearing-impaired children, and a partnership relationship in communicating with them.

The emotional component was represented by the absence of difficulties in understanding the causes of the children's emotional state and an orientation towards the child's emotional state during interactions or physical contact.

Terminal values (such as health, happy family life) and instrumental values (such as responsibility, honesty) were predominant in the value-motivational component.

The behavioral component displayed a predominance of the authoritative style in upbringing, whereby parents realized their important role in the development of a child's personality and recognized the right of children to self-development. At the same time, the authoritarian style was still significant. 
Conclusion. A model for psychological and pedagogical support of families in the upbringing of hearing-impaired children was developed, tested, and found to be effective.

Keywords: parental competence, psychological and pedagogical support, upbringing, hearing-impaired children

\section{Introduction}

Families with hearing-impaired children, as a micro-social system, are characterized by somatic, social, and psychological problems; these can be considered as determinants of the psychological and pedagogical support they receive (Asberg, Vogel, \& Bowers, 2008; Hintermair, 2006; Koester \& Meadow-Orlans, 1990; Koester, Papoušek, \& Smith-Gray, 2000; Molchanova \& Sitnikova, 2015; Pipp-Siegel, Sedey, \& Yoshinaga-Itano, 2002; Quittner, Glueckauf, \& Jackson, 1990; Vaccari \& Marschark, 1997).

Quittner et al. (1990) compared the model of social support for mothers of deaf children and an alternative model based on the participation of a mediator, as well as the possibility of using such models to adapt to chronic stress. They found differences between the functions of social support in chronic and acute stressful conditions of the mothers of deaf children, as well as between specific situational stressors and major life events. The researchers established that chronic parental stress was associated with a lowered perception of emotional support and severe symptoms of depression and anxiety.

Vaccari and Marschark (1997) described the role of early communication between hearing parents and deaf children in the children's social and emotional development, since more than $90 \%$ of deaf children had hearing parents, mostly without effective means of communicating with them. The authors analyzed the interrelations between early communication of hearing parents and the social and emotional development of their deaf children, which become the basis for development of non-verbal strategies for interaction between parents and children.

Pipp-Siegel, Sedey, and Yoshinaga-Itano (2002) presented potential and additional predictors of parental stress among mothers of young hearing-impaired children. They demonstrated that the mothers who perceived their daily problems as more intensive had higher rates of stress. Additional predictors of maternal stress were social support and annual family income.

Kurtzer-White \& Luterman (2003) presented a perspective about chronic parental grief upon the birth of their hearing-impaired child, the parents' coping, and the impact of such chronic grief on the relationship between parents and children .

A study of the correlations among parental resources, social and demographic variables, parental stress, and the social and emotional problems of hearing-impaired children (deaf or hard of hearing), showed that high parental stress was associated with children's social and emotional problems (Hintermair, 2006). The research emphasized the importance of a resource-oriented strategy of counseling and social support in an early intervention process.

The traditional model of psychological and pedagogical support for families in the upbringing of hearing-impaired children currently is considered to be the individual educational route of every child, considering his or her optimal social and psychological adaptation. 
Calderon (2000) examined the impact of parental involvement in deaf education programs on the development of children's language, early reading skills, and social and emotional development. Factors that were considered included extent of hearing loss among the children, mother's education, her communication skills, and the use of additional services (other than those offered by the early intervention program or the relevant school program). The results showed that parental involvement in the school educational program was a significant positive predictor for the development of early reading skills, while maternal communication skills and extent of hearing loss among children were the strongest predictors for the development of language. And although the participation of parents in the school educational program of their deaf children had a positive impact on academic performance, the ability of the child to communicate with the parents is a more significant predictor of positive language and academic development.

We offer a model of psychological and pedagogical support in which families raising hearing-impaired children act as a full and competent subject in the upbringing and educational process carried out by a special needs educational institution.

Our review of Russian and foreign studies of parental competence shows that there is uncertainty both in understanding its essence and offering effective methods for its formation.

The terms "parental competence" (Léonard \& Paul, 1995; Glăveanu, 2015), "psychological competence of parents" (Shagraeva, 2010), "pedagogical competence" (Topilina, 2016), "parental effectiveness", "social and psychological competence of parents", and "competent parenthood" (Cere, 2013; Teti \& Candelaria, 2002) are widely used in the psychological and educational literature. They can be considered as synonyms for "psychological and pedagogical competence of parents" (Korobkova, 2011).

The literature presents several different approaches to an understanding of the essence of "parental competence":

According to the cognitive approach, parental competence is considered as the knowledge, skills, and ways of performing pedagogical activities, as well as the knowledge, skills, and experience of parents in raising children (Glăveanu, 2015; Mizina, 2010). Glăveanu (2015) writes that parental competence is the system of knowledge, skills, abilities, and habits that allow parents to successfully perform their parental duties and prevent/resolve crisis situations, in a way that promotes the development of their children.

The activity approach interprets parental competence as unanimity in the theoretical and practical readiness of parents to perform pedagogical activities, and the ability to understand the needs of children and create conditions to satisfy them (Gladkova, 2009).

The competence approach explains parental competence as a set of personal and activity characteristics manifested in the readiness and ability to accept the children as having value, and successfully socializing them (Selina, 2003; Teti \& Candelaria, 2002). Teti \& Candelaria (2002) define competent parenting only with respect to successful socialization of children. This refers to the parents' mastery of 
competencies based on having the knowledge and skills to actualize them according to the social or educational situation.

The structure of parental competence is also being actively studied, pointing the way to prospects for future research (Gorlova, 2010; Kovalenko 2016), and presenting the main methods and forms of activities related to the development of parental competence (Korobkova, 2011).

Many researchers traditionally distinguish the following components in the structure of parental competence:

1. Value-motivational, personal, cognitive, communicative, creative, and reflective (Mizina, 2010);

2. Motivational and personal, gnostic, communicative, and activity-oriented (Minina, 2013);

3. Motivational and personal, gnostic, communicative, and activity-oriented, competence experience (Sergeeva \& Arakelyan, 2016).

In our view, special needs education supplements each component of parental competence in specific ways, depending on the interaction of its subjects, and the content of solvable psychological and pedagogical tasks posed.

We support the view of Kovalenko (2016) in our model of psychological and pedagogical support for families in the upbringing and education of hearing-impaired children. He writes that competent parents know how to establish a relationship of trust with their children, sense the state they are in, and understand their behavior. Moreover, parental competence is a set of interrelated qualities related to the parent's personality, qualities which are necessary for effective childrearing, including the cognitive, value-motivational, emotional, and behavioral components.

Lectures, conferences, practical exercises, meetings of teachers and parents, training, etc. (Ovcharova, 2006) are considered effective methods for developing parental competence in the upbringing and education of hearing-impaired children. However, acquaintance with age-related patterns in the development of children and methods of self-help are not always provided in work with families of hearing-impaired children.

In this regard, research aimed at specifying which methods for the development of parental competence are the most effective, is an appropriate and popular issue in psychological and pedagogical practice. We assume that the most effective way of working with families raising hearing-impaired children is to combine pedagogical and psychological methods within their support system.

Thus the aim of the present study was to look at the psychological content of parental competence (its cognitive, value-motivational emotional, and behavioral components) and to evaluate the degree to which it is achieved through the psychological and pedagogical support of families raising hearing-impaired children.

The target of the study was families raising hearing-impaired children. The subject was the development of parental competence through psychological and pedagogical support of these families. 


\section{Methods}

\section{Participants}

Eighty-seven families with hearing-impaired children from Kursk Boarding School, a special needs educational institution, participated in the study. During the school year, the parents interact with their children approximately one day a week or every two weeks. The age of all parents was between 25 and 46 years. Eighteen of them had a higher education, 25 had secondary vocational education, 26 had primary vocational, and 18 had secondary education. The group of mothers was aged $\dot{X}_{1} \pm \sigma=34.6 \pm 5.1$; with higher education -13 , secondary vocational 16 , primary vocational -7 , and secondary -5 . The group of fathers was aged $\dot{\mathrm{X}}_{1} \pm \sigma=39.5 \pm 5.6$; with higher education -5 , secondary vocational -9 , primary vocational -19 , and secondary -13 . The 87 children were aged $\dot{X}_{1} \pm \sigma=9.5 \pm 1.8$ and comprised of 39 boys and 48 girls. Twenty children had the first degree of hearing impairment, 26 - the second degree, 19 the third degree, and 22 the fourth degree.

\section{Instruments and Measurement Procedures}

The experimental study involved two stages: baseline and followup. The baseline stage assessed the psychological content of parental competence (its cognitive, value-motivational, emotional, and behavioral components), while the followup stage evaluated the development of parental competence through psychological and pedagogical support for the families raising hearing-impaired children.

The baseline and followup stages used the Russian version of the Rokeach Value Survey (Rokeach, 1973), a questionnaire on emotional relationships in families (Zakharova, 1997), and a questionnaire for parents that identifies the specifics of the communication between parents and children, as well as levels of upbringing activities (Zvereva \& Krotova, 2009).

Statistical processing of the results was performed with Statistica 11.0. Descriptive and comparative statistics were used in the quantitative and qualitative evaluation of the data (statistical criterion for the significance of the differences $\left(\varphi^{*}\right)$ of the angular Fisher transformation).

\section{Procedure}

The study was performed in several stages.

The first stage included motivation of the parents and giving them information about the tasks, objectives, expected results, and practical importance of the study. It ended with their signing a statement of informed consent. Instructions based on the psychological and diagnostic materials were given to all participating parents.

The second stage was the experimental study.

The third stage involved the statistical processing of the primary results. The psychological content of parental competence (its cognitive, value-motivational, emotional, and behavioral components) was studied with the help of descriptive statistics. Parental competence was evaluated by comparative analysis (statistical criterion for the significance of the differences $\left(\varphi^{*}\right)$ of the angular Fisher transformation). Fisher's exact test makes it possible to evaluate the reliability of the dif- 
ferences between the percentages of two samples based on the significance of the effect of interest to the researcher (Sidorenko, 2006).

The fourth stage included analysis and generalization of the results and the drawing of conclusions.

\section{Results}

Diagnostics of the cognitive component of parental competence used the questionnaire for parents (Zvereva \& Krotova, 2009). The objective of the questionnaire was to identify the parents' understanding of the need to develop communication skills, to observe ethical standards in communicating with their child and in interpersonal communication in the child's presence. The specifics of communication between parents and children were also correlated with the level of upbringing activities of parents and the level of their own communication skills (high/medium/low). Three such indicators as the parents' understanding of the need to develop skills for interpersonal communication, adherence to ethical communication with the child, and norms of interpersonal communication among themselves in the child's presence are the criteria used to evaluate them.

Zvereva and Krotova's (2009) questionnaire for parents did not reveal anyone with a high level of upbringing activities or communication skills (0\%); rather the level of upbringing activities and communication skills of the 61 parents was average $(70 \%)$.

Unanimity in approach to upbringing was not always seen in such families. Both a dominating position and communication on equal terms were noted in the parents' communication with their child. Hearing-impaired children were affected not only by instructions, but also by explanations, suggestions, and requests.

Twenty-six parents (30\%) had a low skill level for upbringing activities and communication skills. No unanimity between the parents was found in their upbringing. A dominating position was seen in those parents' communication with their children. The hearing-impaired children were affected mainly by instructions; requests were rarely used, and explanations almost never. The parents often pretended that they were listening to their children, rarely understood their mood, and did not take it into account when choosing activities. Also, the parents indicated that their families had no need to develop interpersonal communication skills, including norms for communicating with each other.

Thus, the predominance of middle and low levels of upbringing activities of the parents with hearing-impaired children testified to an insufficient cognitive component of parental competence, a predominant lack of understanding of the need to develop interpersonal communication skills and to observe ethical means of communicating with the children and each other.

A repeat diagnosis identified a high level of parental upbringing activities and communication skills among 24 parents (28\%). Sixty-three parents $(72 \%)$ had an average level of upbringing and communication skills.

In these families there was mostly unanimity between the parents in their upbringing and they communicated with their children mostly on an equal footing. They affected the hearing-impaired child through explanations and requests. Skills and norms of interpersonal communication were developed. A low level of up- 
bringing and communication skills was identified in one parent (1\%) at followup (in comparison with 26 parents (30\%) at baseline).

Thus, the predominance of high and medium levels of upbringing activities of parents with hearing-impaired children indicates sufficient development of the cognitive component of their parental competence, the predominant understanding among the parents of the need to develop skills of interpersonal communication, and the observance of ethical communication with the children and each other.

The method of the Rokeach Value Survey (Rokeach, 1973) was used in diagnosing the value-motivational component of parental competence. According to Rokeach, "terminal values" are the ultimate goals of individual existence toward which it is necessary to strive (values-goals), and "instrumental values" are the means of achieving those goals (values-means).

The parents in our study were presented with two lists of values (18 in each list): terminal and instrumental. A rank number was assigned to each value according to its significance.

The ratings of the terminal values of parents at baseline and followup are presented in Table 1.

Table 1

Distribution of terminal values of parents with hearing-impaired children

\begin{tabular}{lccccc}
\hline \multicolumn{1}{c}{ Indicators of value } & $\begin{array}{c}\text { NF at } \\
\text { baseline }\end{array}$ & $\begin{array}{c}\text { NF at } \\
\text { followup }\end{array}$ & $\begin{array}{c}\text { PF at } \\
\text { baseline }\end{array}$ & $\begin{array}{c}\text { PF at } \\
\text { followup }\end{array}$ & $\boldsymbol{\varphi}^{*}$ \\
\hline Health & 27 & 29 & 31 & 33 & $10.59^{*}$ \\
Happy family life & 11 & 14 & 13 & 16 & $41.34^{*}$ \\
Interesting work & 9 & 8 & 10 & 9 & 0.07 \\
Financial security & 9 & 8 & 8 & 7 & 0.07 \\
Friends & 7 & 6 & 8 & 7 & 0.08 \\
Love & 8 & 7 & 9 & 8 & 0.08 \\
Life wisdom & 6 & 5 & 7 & 6 & 0.10 \\
Self-confidence & 5 & 4 & 8 & 7 & 0.12 \\
Happiness of others & 5 & 4 & 6 & 5 & 0.12 \\
Freedom & 2 & 2 & 2 & 2 & 0.00 \\
Total & 87 & 87 & 100 & 100 & \\
\hline
\end{tabular}

Note. NF - Number of families. PF - Percentage of families. $\varphi-$ Fisher test: ${ }^{\star} p \leq 0.001$

The results at baseline showed that the leading terminal values of parents with hearing-impaired children were: health, happy family life, interesting work, and financial security.

The triad of significant terminal values, as shown by the results at followup, still included the values of health, happy family life, and interesting work. 
The values health $\left(\varphi^{*}=10.59\right.$ with $\left.\mathrm{p}=0.000\right)$ and happy family life $\left(\varphi^{*}=41.34\right.$ with $\mathrm{p}=0.000$ ) consistently led the frequency distribution (see Table 1 ). The predominance of the health value was predictable among families raising hearing-impaired children, as concern about health care was associated with its psychological and physiological characteristics.

At the same time, the significance of interesting work and financial security decreased slightly compared to the baseline stage. The low significance of freedom in the lives of these families may have been determined by excessive demands on the parents at their jobs.

The instrumental values of parents with hearing-impaired children, considered as the means to achieve the terminal values and as characterological features necessary to realize the instrumental values, are represented in Table 2:

Table 2

Distribution of instrumental values of parents with hearing-impaired children

\begin{tabular}{lccccc}
\hline \multicolumn{1}{c}{ Indicators of value } & $\begin{array}{c}\text { NF at } \\
\text { baseline }\end{array}$ & $\begin{array}{c}\text { NF at } \\
\text { followup }\end{array}$ & $\begin{array}{c}\text { PF at } \\
\text { baseline }\end{array}$ & $\begin{array}{c}\text { PF at } \\
\text { followup }\end{array}$ & $\boldsymbol{\varphi}^{*}$ \\
\hline Responsibility & 21 & 14 & 24 & 16 & $32.51^{*}$ \\
Honesty & 13 & 16 & 15 & 18 & $36.10^{*}$ \\
Rationality & 11 & 11 & 12 & 13 & 0.00 \\
Education & 10 & 10 & 11 & 11 & 0.00 \\
Accuracy & 8 & 6 & 9 & 7 & 0.31 \\
Tolerance & 7 & 10 & 8 & 11 & $52.90^{*}$ \\
Cheerfulness & 7 & 5 & 8 & 6 & 0.36 \\
Strong will & 5 & 5 & 6 & 6 & 0.00 \\
Sensitivity & 3 & 8 & 3 & 9 & $68.60^{*}$ \\
Independence & 2 & 2 & 2 & 2 & 0.00 \\
Total & 87 & 87 & 100 & 100 & \\
\hline
\end{tabular}

Note. NF - Number of families. PF - Percentage of families. $\varphi-$ Fisher test: ${ }^{\star} p \leq 0.001$

As for the results at baseline, a high distribution of responsibility, honesty, and rationality in the list of instrumental values proved significant in harmonizing the marital relationship. Parents with hearing-impaired children tried to create the best material conditions for them and worried about their health and well-being. The parents tried to protect their children from various difficulties, blocking their contact with people outside the family, so that the children get their life experience outside the home. The parents' behavior was characterized by constant intrusions into their children's world.

The triad of significant terminal values at followup also included responsibility, honesty, and rationality.

The values of responsibility $\left(\varphi^{*}=32.51\right.$ with $\left.p=0.000\right)$ and honesty $\left(\varphi^{*}=36.10\right.$ with $\mathrm{p}=0.000)$ consistently led the frequency distribution, although the value of 
responsibility, which might be interpreted as hyper-responsibility, significantly decreased. The high rating of the value of honesty demonstrated its importance and the need to harmonize the marital relationship.

The significance of tolerance $\left(\varphi^{*}=52.90\right.$ with $\left.\mathrm{p}=0.000\right)$ and sensitivity $\left(\varphi^{*}=68.60\right.$ with $\left.p=0.000\right)$ increased in statistical significance. The value of independence had low positions (2\%) on the list of instrumental values (see Table 2). This might be explained by excessive demands on the parents at their jobs.

Such characteristic features as responsibility, honesty, rationality, tolerance, and sensitivity - both in the marital relationship and in the relationship between parents and children - made it possible to preserve the integrity of the family as a micro-social system, to care for their children's health, and to ensure a happy and financially secure family life and a successful career.

The questionnaire on the family's emotional relationship (Zakharova, 1997), indirectly revealing the expression of such values as sensitivity, emotional acceptance, and behavioral manifestations of emotional interaction, was used to diagnose the emotional component of parental competence.

That emotional component at baseline was characterized by the following sensitivity: parents' average ability to perceive the child's state $\left(\mathrm{X}_{\mathrm{av}}=3.77\right.$, $\left.\mathrm{X}_{\mathrm{cr}}=4.22 \pm 0.52\right)$ and average empathy $\left(\mathrm{X}_{\mathrm{av}}=3.17, \mathrm{X}_{\mathrm{cr}}=3.39 \pm 0.59\right)$, but insufficient understanding of the causes of that state: $\left(\mathrm{X}_{\mathrm{av}}=2.21, \mathrm{X}_{\mathrm{cr}}=3.85 \pm 0.65\right)$, and insufficient emotional acceptance of the child: mother's feelings during interaction with her child $\left(X_{\mathrm{av}}=3.64, \mathrm{X}_{\mathrm{cr}}=3.9 \pm 0.6\right)$, unconditional acceptance $\left(\mathrm{X}_{\mathrm{av}}=3.47, \mathrm{X}_{\mathrm{cr}}=3.84 \pm 0.64\right)$, acceptance of oneself as a parent $\left(\mathrm{X}_{\mathrm{av}}=3.67\right.$, $\left.\mathrm{X}_{\mathrm{cr}}=3.78 \pm 0.68\right)$, predominant emotional ambiance of the interaction $\left(\mathrm{X}_{\mathrm{av}}=3.61\right.$, $\left.\mathrm{X}_{\mathrm{cr}}=3.66 \pm 0.66\right)$.

In behavioral manifestations of emotional interaction, parents experienced difficulties making physical contact with their hearing-impaired children $\left(\mathrm{X}_{\mathrm{av}}=3.22\right.$, $\left.\mathrm{X}_{\mathrm{cr}}=4.03 \pm 0.73\right)$ and in orienting to the child's state during the interaction $\left(\mathrm{X}_{\mathrm{av}}=2.03, \mathrm{X}_{\mathrm{cr}}=2.95 \pm 0.65\right)$. However, they did affect the child's state $\left(\mathrm{X}_{\mathrm{av}}=3.85\right.$, $\left.\mathrm{X}_{\mathrm{cr}}=3.8 \pm 0.6\right)$ and tried to provide the child with emotional support $\left(\mathrm{X}_{\mathrm{av}}=3.31\right.$, $\left.\mathrm{X}_{\mathrm{cr}}=3.47 \pm 0.67\right)$.

The parents had no difficulty in understanding the reasons for the child's state, however (baseline: $\mathrm{X}_{\mathrm{av}}=2.21, \mathrm{X}_{\mathrm{cr}}=3.85 \pm 0.65$; followup: $\mathrm{X}_{\mathrm{av}}=3.36, \mathrm{X}_{\mathrm{cr}}=3.85 \pm 0.65$ ); they tried to make physical contact (baseline: $\mathrm{X}_{\mathrm{av}}=3.22, \mathrm{X}_{\mathrm{cr}}=4.03 \pm 0.73$; followup: $\mathrm{X}_{\mathrm{av}}=3.7 ; \mathrm{X}_{\mathrm{cr}}=4.03 \pm 0.73$ ) and to orient to the child's state during interactions (baseline: $\mathrm{X}_{\mathrm{av}}=2.03, \mathrm{X}_{\mathrm{cr}}=2.95 \pm 0.65$; followup: $\mathrm{X}_{\mathrm{av}}=2.42, \mathrm{X}_{\mathrm{cr}}=2.95 \pm 0.65$ ).

The behavioral component of parental competence at baseline and followup was diagnosed using the Stepanov Styles of Parental Behavior questionnaire (Stepanov, 2000). This instrument allowed us to identify the parents' strategy in raising their hearing-impaired children.

We defined "upbringing activities" as those determining the main lines of childrearing personal qualities, expansion of their horizons, acquainting them with cultural values, direction and support of the children's activities.

At baseline, the predominant style of upbringing was authoritarian. Fifty-six parents (64\%) displayed exactingness and strictness, and had quite clear ideas about how their children should grow up. The liberal style was found among 17 parents (20\%). Those parents trusted their children, considered their weaknesses 
forgivable, communicated with them on equal grounds, and were not inclined to use prohibitions and restrictions. An indifferent style was seen in 13 parents (15\%). They were busy with their work, and problems of raising their children were not their priority. The children were left alone, did not receive support and help in difficult situations, made their own decisions, and resolved their own problems as well as they could. An authoritative style of upbringing was scarcely found at all (1\%).

This suggests that the parents were not fully aware of their important role in the development of their child's personality and did not recognize the child's and their own right to self-development. They were not always willing to reconsider their views.

Thus the results showed that a destructive strategy of unconditional subordination of children to their parents and the children's complete dependence on them dominated in the behavioral component of parental competence. This prevented the development of an active personal identity and independence. At the same time, a significant proportion of parents was prone to the liberal and indifferent styles, in which prohibitions and followup were reduced or the children were left to themselves.

In the followup phase of the study, the frequency of the authoritarian style was statistically and significantly decreased $\left(\varphi^{*}=19.37\right.$ with $\left.\mathrm{p}=0.000\right)$. This style was found among 56 parents (64\%) at baseline and 27 parents $(31 \%)$ at followup. This confirmed a significant reduction in hyper-protection and attempts to intrude into the child's world.

The authoritative style of upbringing became significantly more prevalent $\left(\varphi^{*}=46.88\right.$ with $\left.\mathrm{p}=0.000\right)$; one parent $(1 \%)$ was identified at baseline, and 34 parents $(39 \%)$ at followup. The frequency of the liberal style significantly increased $\left(\varphi^{*}=22.75\right.$ with $\left.\mathrm{p}=0.000\right)$. Seventeen parents $(20 \%)$ with this style were found at baseline, and 23 parents (27\%) at followup.

This indicates that the parents trusted their children and communicated with them on an equal footing. The frequency of an indifferent style $\left(\varphi^{*}=24.70\right.$ with $\mathrm{p}=0.000)$ significantly decreased; that style was found only among 3 parents $(3 \%)$ (rather than 13 parents [15\%] at baseline), which indicated that the children felt they had constant support and help in difficult situations.

\section{Discussion}

An important task in modernizing education in the Russian Federation is to ensure the accessibility of quality education, its individualization and differentiation, which implies: psychological and pedagogical assistance and support to families of at-risk children (those requiring special attention); creation of a single space for upbringing and education on the part of families as well as educational institutions, which is only possible with competent parenthood and a partnership between educational institutions and families.

A bibliometric analysis of published works with a search for "parental competence", as shown in the Russian citation index (2008 to 2017), revealed that $0.001 \%$ of the total number of studies found there were similar in nature. Brief analysis of some of them allowed us to see the following semantic contexts in the study of pa- 
rental competence: stage in the development of the adult's personality and the family's resources, as a component of the relationship between parents and children; and characteristics of the relationship between parents and children, considering the children's psychological age and stage in age-related psychological development (Gorlova, 2013).

There are a small number of studies of parental competence in the upbringing of hearing-impaired children, which support the relevance of our study and its results, as well as its scientific novelty. This is also indicated by the results of the bibliometric analysis performed at elibrary.ru with the search phrase: "parental competence in the upbringing of hearing-impaired children". The bibliometric analysis covered 10 years (2008 to 2017), and the total number of publications was two, which corresponds to $7,034-6 \%$.

We considered the process of modeling the interaction between families with hearing-impaired children and special needs educational institutions as analogous to modeling the interaction of families with a primary school. The process consisted of three blocks: purpose-oriented, organizational-substantive, and evaluation of effectiveness (Kovalenko, 2016; Sergeeva \& Arakelyan, 2016).

Our results in the evaluation of parent competence (its cognitive, value-motivational emotional, and behavioral components) with the psychological and pedagogical support of families raising hearing-impaired children were consistent with the results of studies related to the interaction of families and the primary school (Kovalenko, 2016; Sergeeva \& Arakelyan, 2016).

In this regard, the presence of general trends and patterns in the evaluation of effectiveness can be the basis for developing a model of the interaction between families and schools in an inclusive educational environment.

However, comparing our results with those of Kovalenko (2016) shows some discrepancies in the content of the value-motivational, as well as behavioral, components of parental competence when raising hearing-impaired children, in the followup phase of our formative study.

Thus in the value-motivational component of parental competence, the dominant values, in addition to those of "health", "happy family life", and "interesting work", which are typical for parents of primary schoolchildren, were the values "financial security", "honesty", and "rationality".

According to our study, the parents were trying to create the best material conditions for their children, and feared for their health and well-being. The parents raising hearing-impaired children showed responsibility, honesty, rationality, tolerance, and sensitivity in the marital relationship and the relationship between parents and children, in order to preserve the integrity of the family and ensure happy, financially secure family life.

The predominance of the authoritarian style, in addition to the authoritative style of child-rearing, was noted in the behavioral component of parental competence, manifesting exactingness and strictness.

In our view, these values in parental competence in raising hearing-impaired children are due to the psychological and physiological characteristics of the children and hyper-responsibility for their life and health. 


\section{Conclusion}

At baseline, the study of the psychological content of parental competence in the psychological and pedagogical support of families raising hearing-impaired children made it possible to draw the following conclusions.

First, parental competence was represented at the cognitive, value-motivational, emotional, and behavioral levels by the set of interrelated qualities of the parent's personality necessary for effective child-rearing. The structure of parental competence allowed us to determine the content, identify the forms of effective work on its development in accordance with the assigned tasks, the professional competencies of specialists, and the planned results.

Second, regarding the cognitive component of parental competence, we identified the predominant underestimation by the parents of the need to develop interpersonal communication skills, and to observe ethical communication with the children and each other. The emotional component of parental competence was represented by their difficulties in understanding the causes of the children's emotional state, orienting towards their emotional state during the interaction, and making physical contact.

The values of health and happy family life, as well as those of professional selfrealization, were predominant in the value-motivational component of parental competence. The behavioral component of parental competence was dominated by the authoritarian style: exactingness and strictness.

The results of the followup stage of our study allow us to draw the following conclusions:

First, the psychological content of parental competence has significantly changed compared to baseline.

The cognitive component of parental competence is characterized by predominant unanimity in the upbringing of hearing-impaired children and a relationship of partnership in communication with them.

The emotional component of parental competence is represented by the absence of difficulties in understanding the causes of the children's emotional state, an orientation towards their emotional state in interaction with them, and making physical contact.

The values of health, happy family life, interesting work, and financial security, honesty, and rationality are still dominant in the value-motivational component of parental competence. The value of health is predominant. The importance of hyper-responsibility is significantly reduced.

The behavioral component of parental competence is represented by the predominance of the authoritative style of upbringing. Parents perform their important role in the development of the personality of children and recognize the right of the children to self-development. At the same time, the authoritarian style is still significant.

Second, the developed and tested model of the psychological and pedagogical support of families raising hearing-impaired children is effective, since the results demonstrate an increase in parental competence. 
The information in this article can be useful to specialists at special needs educational institutions, as well as to parents who are raising hearing-impaired children, and may be included in the process of psychological and pedagogical support.

The results of the study make it possible to identify problems and prospective directions that require further study. Among these are the following: development of competence on the part of parents with hearing-impaired children, and developing scientific and methodological support to provide parents with psychological and pedagogical support.

\section{Limitations}

The main limitation of the study is that its participants were exclusively parents of hearing-impaired children in one Russian city and one special needs educational institution, located in Kursk. Care should therefore be taken in generalizing the results to non-participant parents of hearing-impaired children. This limitation can be overcome by studying parents of hearing-impaired children from several cities.

Another limitation is that the study did not consider the relationship between siblings, which could provide more details about the families functioning as a micro-social system and that system's impact on parental competence.

In addition, the corporate culture of the special needs educational institution, the level of education and personal characteristics of its employees, and the relationships among them could affect the development of parental competence and should also be considered.

The reliability of the results and conclusions of the study has been demonstrated by various mathematical statistics methods and comprehensive analysis of the data.

\section{References}

Asberg, K.K., Vogel, J.J., \& Bowers, C.A. (2008). Exploring correlates and predictors of stress in parents of children who are deaf: Implications of perceived social support and mode of communication. Journal of Child and Family Studies, 17, 486-499. https://doi.org/10.1007/ s10826-007-9169-7

Calderon, R. (2000). Parental involvement in deaf children's education programs as a predictor of child's language, early reading, and social emotional development. Journal of Deaf Studies and Deaf Education, 5(2) Spring, 140-155. https://doi.org/10.1093/deafed/5.2.140

Cere, D. (2013). What is parenthood? Proposing two models. Toward an integrative account of parenthood. In L.C. McClain \& D. Cere (Eds.), What is parenthood? Contemporary debates about the family (pp. 19-40). New York: New York University Press. https://doi. org/10.18574/nyu/9780814729151.003.0001

Gladkova, Yu.A. (2009). Deyatel'nost' doshkol'nogo uchrezhdeniya po povysheniyu psikhologopedagogicheskoi kul'tury sovremennoi sem'i: avtoref. dis. ...kand. ped. nauk. [Activities of preschool institutions to enhance the psychological and pedagogical culture of the modern family. Author's abstract. dis. ... candidate of pedagogical sciences]. Moscow: Moscow City Pedagogical University.

Glăveanu, S.M. (2015). The parental competence of single-parent families from vulnerable groups. Procedia - Social and Behavioral Sciences, 187(13), 201-205. https://doi. org/10.1016/j.sbspro.2015.03.038 
Gorlova, E.L. (2010). Roditel'skaya kompetentnost': podkhody k izucheniyu i razvitiyu [Parental competence: Approaches to learning and development]. Vestnik RGGU. Seriya: Psikhologiya. Pedagogika. Obrazovanie [Bulletin of the RSUH. Series: Psychology. Pedagogy. Education], 17(60), 214-224.

Gorlova, E.L. (2013). Psikhologicheskii vozrast rebenka kak osnovanie dlya proektirovaniya strategii razvitiya roditel'skoi kompetentnosti [Psychological age of the child as a basis for designing strategies for the development of parental competence]. Natsionalnyi psikhologicheskii zhurnal. [National Psychological Journal], 2(10), 134-141. https://doi. org/10.11621/npj.2013.0217

Hintermair, M. (2006). Parental resources, parental stress, and socioemotional development of deaf and hard of hearing children. Journal of Deaf Studies and Deaf Education, 11(4), 493513. https://doi.org/10.1093/deafed/enl005

Kabanchenko, E.A., \& Kholodkova, O.G. (2017). K probleme roditel'skoi kompetentnosti v sem'yakh, vospityvayushchikh detei s OVZ [On the problem of parental competence in families raising children with disabilities]. In G.Yu. Lizunova (Eds.), Tsennostnye orientatsii molodezhi $v$ usloviyakh modernizatsii sovremennogo obshchestva Sbornik nauchnykh trudov. [Value orientations of youth in conditions of modernization of modern society] (pp. 309312). Gorno-Altaisk: Gorno-Altaisk State University.

Kliukvina, A.Yu. (2015). Teoreticheskie aspekty issledovaniya problemy kompetentnosti roditelei, imeyushchikh detei doshkol'nogo i mladshego shkol'nogo vozrasta s intellektual'noi nedostatochnost'yu [Theoretical aspects of the study of the problem of the competence of parents with children of preschool and primary school age with intellectual impairment]. Vestnik Moskovskogo gorodskogo pedagogicheskogo universiteta. Seriya: Pedagogika i psikhologiya [Bulletin of Moscow City Pedagogical University. Series: Pedagogy and psychology], 1(31), 86-95.

Koester, L., \& Meadow-Orlans, K. (1990). Parenting a deaf child: Stress, strength, and support. In D. Koester \& K. Meadow-Orlans (Eds.), Educational and developmental aspects of deafness (pp. 299-320). Washington, DC: Gallaudet University Press.

Koester, L.S., Papoušek, H., \& S. Smith-Gray (2000). Intuitive parenting, communication, and interaction with deaf infants. In P.E. Spencer, C.J. Erting, \& M. Marschark (Eds.), Essays in honor of Kathryn P. Meadow-Orlans: The deaf child in the family and at school (pp. 55-71). Mahwah, NJ: Lawrence Erlbaum Associates.

Korobkova, V.V. (2011). Sushchnost' i soderzhanie psikhologo-pedagogicheskoi kompetentnosti roditelei $v$ sovremennykh issledovaniyakh [The essence and content of parents' psychologi$\mathrm{cal}$ and pedagogical competence in contemporary research]. Pedagogicheskoe obrazovanie i nauka [Pedagogical education and science], 6, 101-105.

Kovalenko, T.V. (2016). Modelirovanie vzaimodeistviya sem'i i shkoly v usloviyakh sovremennogo nachal'nogo obrazovaniya: avtoref. dis. ...kand. ped. nauk. [Modeling the interaction between family and school in the context of modern primary education. Author's abstract. dis. ... candidate of pedagogical sciences]. Omsk: Omsk State Pedagogical University.

Kurtzer-White, \& E., Luterman, D. (2003). Families and children with hearing loss: Grief and coping. Mental Retardation and Developmental Disabilities Research Reviews, 9(4), 232235. https://doi.org/10.1002/mrdd.10085

Léonard, N., \& Paul, D. (1995). La vie du couple et les sentiments de compétence parentale [The life of the couple and feelings of parental competence]. Can. Nurse, 91(9), 42-45.

Minina, A.V. (2013). Struktura i soderzhanie pedagogicheskoi kompetentnosti roditelei v vospitanii samostoyatel'nosti u detei doshkol'nogo vozrasta [Structure and content of pedagogical competence of parents in the education of independence in preschool children]. 
Obrazovanie. Nauka. Innovatsii: Yuzhnoe izmerenie [Education. Science. Innovations: The Southern Dimension]. Rostov-on-Don: Southern Federal University, 2, 93-98.

Misina, N.N. (2009). Roditel'skaya kompetentnost': psikhologicheskii aspekt problemy [Parental competence: the psychological aspect of the problem]. Nauchnykh trudov Severo-Kavkazskogo gosudarstvennogo tekhnicheskogo universiteta. Gumanitarnye nauki [Scientific papers of the North Caucasus State Technical University. Humanitarian sciences], 7. Stavropol: North Caucasus State Technical University. Retrieved from: http://science.ncstu.ru/articles/ hs/2009_07/psychology.

Molchanova, L.N., \& Sitnikova, A.V. (2015). Osobennosti funktsionirovaniya semei, vospityvayushchikh detei $s$ narusheniem slukha [Features of the functioning of families raising children with hearing impairment]. Korrektsionno-pedagogicheskoe obrazovanie [Correction and pedagogical education], 3(3), 16-27.

Ovcharova, R.V. (2006). Roditel'stvo kak psikhologicheskii fenomen [Parenthood as a psychological phenomenon]. Textbook. Moscow: Moscow Psychological and Social Institute.

Petukhova, A.V. (2012). Povyshenie urovnya kompetentnosti semei, imeyushchikh detei s rechevymi narusheniyami cherez integratsiyu raboty uchitelya-logopeda i pedagoga-psikhologa [Raising the level of competence of families of children with speech impairments through the integration of the work of a speech therapist and a psychologist]. Nauchnye trudy SWorld [Scientific works SWorld], 17, 3-5.

Pipp-Siegel, S., Sedey, A.L., \& Yoshinaga-Itano, C. (2002). Predictors of parental stress in mothers of young children with hearing loss. Journal of Deaf Studies and Deaf Education, 7(1), 1-17. https://doi.org/10.1093/deafed/7.1.1

Popova, S.Yu., \& Nogovitsyna, N.M. (2017). Rol' obshcheobrazovatel'nykh uchrezhdenii v povyshenii roditel'skoi kompetentnosti [The role of general education institutions in improving parental competence]. Nauchno-metodicheskii elektronnyi zhurnal Kontsept [Concept. Scientific and methodical electronic journal], 26, 192-194.

Quittner, A.L., Glueckauf, R.L., \& Jackson, D.N. (1990). Chronic parenting stress: Moderating versus mediating effects of social support. Journal of Personality and Social Psychology, 59, 1266-1278. https://doi.org/10.1037/0022-3514.59.6.1266

Rokeach, M. (1973). The nature of human values. New York: The Free Press. Russian version: Metodika Rokicha “Tsennostnye orientatsii”. Retrieved from: http://psycabi.net/testy/320metodika-rokicha-tsennostnye-orientatsii-test-miltona-rokicha-issledovanie-tsennostnykh-orientatsij-m-rokicha-oprosnik-tsennosti-po-rokichu.html.

Selina, V.V. (2009). Razvitie pedagogicheskoi kompetentnosti roditelei detei rannego vozrasta $v$ doshkol'nom obrazovatel'nom uchrezhdenii: dis. ... kand. ped. nauk [Development of the pedagogical competence of parents of young children in preschool educational institutions: dis. ... candidate of pedagogical sciences]. Novgorod: Novgorod State University.

Sergeeva, B.V., \& Arakelyan, R.K. (2016). Formirovanie roditel'skoi kompetentnosti v usloviyakh nachal'noi shkoly [Formation of parental competence in the conditions of an elementary school]. Istoricheskaya i sotsial'no-obrazovatel'naya mysl' [Historical and social-educational thought], 8, 1(1), 184-188. https://doi.org/10.17748/2075-9908-2016-8-1/1-184-188.

Shagraeva, O.A. (2010). Kategoriya "psikhologicheskaya kompetentnost' roditelei" v svete osnovnykh polozhenii kontseptsii P.Ya. Gal'perina [The category "psychological competence of parents" in light of the main provisions of the concept of P.Ya. Galperin]. Psikhologiya i pedagogika: metodika i problemy prakticheskogo primeneniya [Psychology and pedagogy: methods and problems of practical application], 16(2), 264-271.

Sidorenko, E.V. (2006). Metody matematicheskoi obrabotki v psikhologii [Methods of mathematical processing in psychology]. St. Petersburg: Rech'. 
Stepanov, S. (2000). Oprosnik S. Stepanova "Stili roditel'skogo povedeniya” [S. Stepanov "Styles of parental behavior" questionnaire]. Retrieved from: http://skorova.spb.ru/?mode=test19.

Teti, D.M. \& Candelaria, M.A. (2002). Parenting competence. In Marc H. Bornstein (Ed.), Handbook of parenting (pp. 149 -180). Mahwah, NJ: Lawrence Erlbaum Associates.

Topilina, N.V. (2016). Pedagogicheskie sposobnosti i kompetentsii roditelei v sovremennoi pedagogicheskoi praktike [Pedagogical abilities and competence of parents in modern pedagogical practice]. Innovatsionnaya nauka [Innovative science], 2-4, 136-139.

Vaccari, C., \& Marschark, M. (1997). Communication between parents and deaf children: Implications for social-emotional development. Journal of Child Psychology and Psychiatry, 38(7), 793-801. https://doi.org/10.1111/j.1469-7610.1997.tb01597.x

Vlaykova, K.V. (2010). Vklyuchenie roditelei v korrektsionno-razvivayushchii protsess kak odna iz form raboty po povysheniyu roditel'skoi kompetentnosti [Inclusion of parents in the correctional-development process as one of the forms of work to improve parental competence]. Vospitanie i obuchenie detei s narusheniyami razvitiya [Education and training of children with developmental disabilities], 4, 55-57.

Zakharova, E.I. (1997). Oprosnik emotsional'nykh otnoshenii v sem'e [Questionnaire of emotional relations in the family]. Retrieved from: https://pro-psixology.ru/psixologicheskoeobsledovanie-semi/606-oprosnik-yemocionalnyx-otnoshenij-v-seme-ei.html

Zvereva, O.L., \& Krotova, T.V. (2009). Obshchenie pedagoga s roditelyami v DOU: Metodicheskii aspekt [Questionnaire for parents. Communication of the teacher with parents in preschool: Methodological aspect]. Moscow: Sfera.

Original manuscript received August 04, 2018

Revised manuscript accepted September 30, 2018

First published online December 30, 2018 